\title{
DAILY ACTIVITIES OF BALI MYNA (Leucopsar rothschildi) AT BALI MYNA GUIDANCE CENTER, TEGAL BUNDER, BALI BARAT NATIONAL PARK
}

\author{
Arista Setyaningrum 1,2, Pipit Noviyani 1,2, Bambang Agus Suripto 2,* \\ 'Matalabiogama, ${ }^{2}$ Fakultas Biologi Universitas Gadjah Mada, ${ }^{*}$ supervisor \\ e-mail: aristasetyaningrum@mail.ugm.ac.id
}

\section{INTRODUCTION}

Bali Myna (Leucopsar rothschildl) is Bali's endemic bird. Their number is decreasing gradually in the wild (Balen et al., 2000). Its bright color of white feather and blue skin that surrounded its eye have made them easy to be hunted when it perched on abranch. Bali Myna was classified as endangered species by International Union of Conservation and Natural resources (IUCN) in 1977 (Whitten et al. 1999). There is a captive breeding in Tegal Bunder, Bali Barat National Park (BBNP) called Bali Myna Guidance Centre to increase wild population as an effort to prevent extinction. There, its conditions should be monitored regularly to keep them in prime condition, before being released for breeding purpose. Their condition could be controlled by monitoring their daily activities.

\section{Objectives}

1. How were the categories of Bali Myna at Bali Myna Guidance Center, Tegal Bunder, BBNP?

2. How are Bali Myna daily activities according to its category?

\section{MATERIALS AND METHODS}

This study used tools such as (1) binocular to observe the bird, (2) table to record Bali Myna activities, and (3) digital camera for documentation. This study was conducted on July 17th - August 5th, 2012 in Bali Myna Guidance Center, Tegal Bunder, Bali Barat National Park (BBNP). The daily activities of Bali Myna was observed using scanning or direct observation, a modified method based on the study done by Dimitra et al. (2011) and Gunawan (2004). Further, several interview were also done towards forest ranger and animal keeper in order to gain information on cage category. Observation of daily activities was held at 6:00 AM until 6:00 PM with a capture time of 10 minutes in each hour for 10 days. A preobservation was conducted 2 days prior, to record some new activities that were previously unrecorded during earlier studies.

\section{RESULT AND DISCUSSION}

The result of the interview towards forest ranger and animal keeper showed five cage categories that are summarized in Table 1. 
Table 1. Bali Myna's cage category in Bali Myna Guidance Center, Tegal Bunder, Bali Barat National Park (BBNP).

\begin{tabular}{|c|c|c|c|}
\hline No. & Cage Category & Description & Picture \\
\hline 1 & Breeding cage & $\begin{array}{l}\text { Include several mature Bali } \\
\text { Myna that are productive } \\
\text { for breeding }\end{array}$ & \\
\hline 2 & Weaning cage & $\begin{array}{l}\text { Include by 3-7 months old } \\
\text { Bali Myna. } \\
\text {-colony } \\
\text {-to control the competition } \\
\text { among birds as an early } \\
\text { step to being release }\end{array}$ & \\
\hline 3 & $\begin{array}{l}\text { Mother to be } \\
\text { cage }\end{array}$ & $\begin{array}{l}\text {-Housed by Immature Bali } \\
\text { Myna that fulfill criteria to } \\
\text { be mother } \\
\text {-to get Bali Myna mature } \\
\text { couple }\end{array}$ & \\
\hline 4 & Quarantine cage & $\begin{array}{l}\text { Was used to care for Bali } \\
\text { Myna that are physically or } \\
\text { psychologically ill, new } \\
\text { comer birds, new weaning } \\
\text { birds. }\end{array}$ & 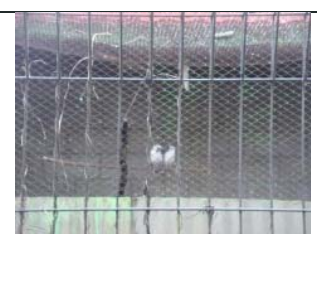 \\
\hline 5 & $\begin{array}{l}\text { Kandang } \\
\text { Kubah/ pra- } \\
\text { pelepasliaran }\end{array}$ & $\begin{array}{l}\text { - Housed by } 7-12 \text { months } \\
\text { old Bali Myna that are } \\
\text { healthy, as confirmed by } \\
\text { veterinary } \\
\text {-usually coupled }\end{array}$ & \\
\hline
\end{tabular}

Every cage is housed by birds with an average age that specified for breeding or for being released. As an effort to monitor their condition, daily activities of birds in each cage were observed. Birds in each cage showed different percentage of activities as showed at Figure 1.

The birds started their day at 6:00 AM and rested at 6:00 PM. The observation showed 20 varieties of activities with the highest percentage being stationer. Stationer indicates that the birds did not move from one location to another however though they continue to perform other activities such as voicing, sun bathing, body cleaning, flying, etc. There was no significant difference among each cage. For further study, it's important to compare daily activities between the wild bird and the birds that were kept in this place. 


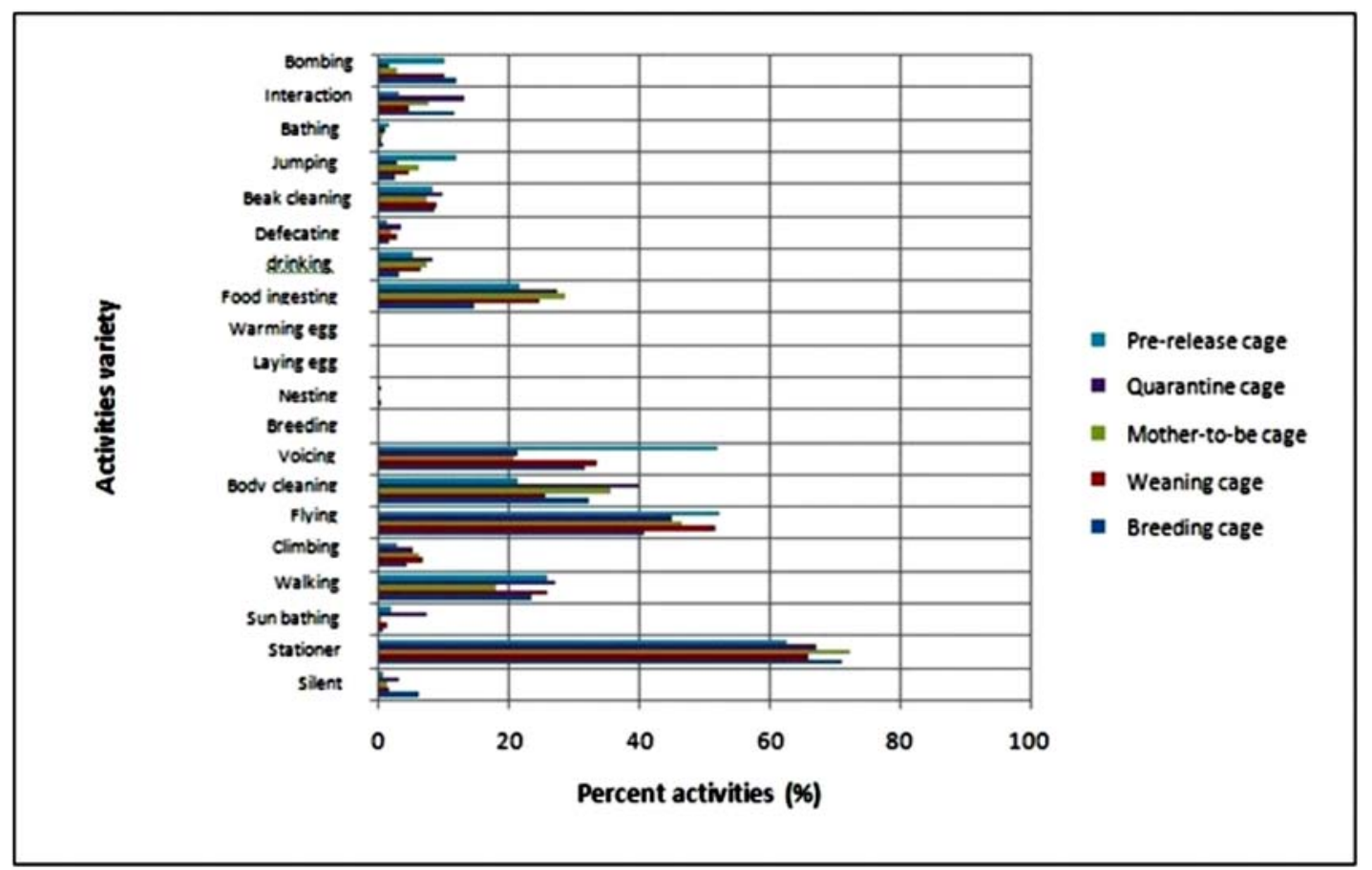

Figure 1. Activity percentage of Bali Myna for a day.

\section{CONCLUSIONS}

1. Bali Myna in Bali Myna Guidance Center, Tegal Bunder, Bali Barat National Park (BBNP) were categorized according to age and purpose on coaching in five categories as breeding cage, weaning cage, mother-to-be cage, pre-release cage, and quarantine cage.

2. There were 20 activities recorded with the highest activity being stationer. Daily activities of Bali Myna in each cage had no significant differences in any enclosure.

\section{REFERENCES}

Balen, S.V., I.A. Dirgayusa, I. W. A.Putra, and H. H. T. Prins. 2000. Status and distribution of the endemic Bali starling Leucopsar rothschildi. Oryx Vol. 34(3).

Dimitra, A. , I. Mustofa, D. Kusnoto, D. Legowo, B. Kusumawat, and Setiawan. 2011. Studi Perilaku Pasangan Curik Bali (Leucopsar rothschildi) Pada Kandang Breeding Di Kebun Binatang Surabaya (Study The Couples Of Bali Starlings (Leucopsar rothschildi) On Breeding Cages At Surabaya Zoo). Artikel ilmiah. Universitas Airlangga: Surabaya. Gunawan. 2004. Perilaku elang laut perut putih (Haliaeetus leucogaster, J.M.Gmelin, 1788) di Pusat Penyelamat Satwa Jogjakarta (PPSJ). Skripsi. Fakultas Biologi Universitas Gadjah Mada Yogyakarta.

Whitten, T., R.E. Soeriaatmadja, and S.A. Afiff. 1999. Ekologi jawa dan bali. Seri Ekologi Indonesia, Jilid II. PT Prenhallindo, Jakarta. Hal: 706-712, 826-829. 